\title{
ЛЕЙОМІОСАРКОМА МАТКИ (ВИПАДОК ІЗ ПРАКТИКИ)
}

\author{
ФЯ. Я. Боднар, Ю. М. Орел, П. С. Крижан, Л. П. Боднар
}

ДВНЗ «Тернопільський державний медичний університет імені І. Я. Горбачевського МОз України»

РЕзюмЕ. Серед злоякісних пухлин матки лейоміосаркома зустрічається в 1-1,3 \% випадків. Найчастіше цю пухлину виявляють при вивченні операційного матеріалу, тому саме гістологічне дослідження $є$ основним методом діагностики лейоміосаркоми матки. При цьому часто виникають труднощі у диференціації цієї пухлини та її доброякісного аналога - лейоміоми. У публікації описаний випадок лейоміосаркоми матки у жінки віком 51 р. Детально репрезентовані анамнестичні та клінічні дані, описано динаміку розвитку захворювання. Основну увагу зосереджено на критеріях мікроскопічної діагностики лейоміосаркоми матки. Так, при гістологічному дослідженні операційного матеріалу виявлено суттєві прояви ремоделювання гладких м'язів міометрія. Ядра міоцитів мали ознаки виродливості, набували великих розмірів, ставали гіперхромними, що є індикатором дистрофічних процесів внаслідок невідповідності між кровопостачанням і проліферацією клітин у злоякісній пухлині. Поліморфізм ядер спостерігався дифузно, а не осередково. Окрім того, візуалізувалися патологічні мітози, некрози, крововиливи. Описаний випадок із практики акцентує увагу патоморфологів на труднощах гістологічної верифікації лейоміосаркоми і міоми матки.

КлючОВІ СлОВА: лейоміосаркома; матка; гістологічна діагностика.

Вступ. Гістологічна диференціація лейоміосарком та проліферативних міом належить до найскладніших питань онкоморфології $[1,3]$. Лейоміосаркома маткиуклінічній практиці діагностується досить рідко - приблизно 6 випадків на мільйон жінок [4]. Загалом у структурі злоякісних пухлин матки ії частка складає 1-1,3 \% [5]. Клінічно лейоміосаркома подібна до лейоміоми. Зустрічається у жінок віком понад 40 років, зазвичай проявляється кровотечами (56 \%), збільшенням розмірів матки $(54 \%)$ і болем внизу живота $(23 \%)[5,7]$.

Найчастіше діагноз лейоміосаркоми встановлюють випадково, при гістологічному вивченні операційного матеріалу. Саме морфологічний метод дослідження $\epsilon$ ключовим для діагностики цієї пухлини, оскільки дає змогу диференціювати лейоміосаркому і її доброякісний аналог - лейоміому $[1,8]$.

Доцільно зазначити, що гістологічні варіанти лейоміосаркоми досить різноманітні: «чисті», що походять із одного структурного компонента (лейоміосаркома, ендометріальна стромальна саркома), і змішані - із мезодермального та епітеліального компонентів (карциносаркома). В окремих випадках розрізняють ще один варіант пухлини міксоїдну лейоміосаркому [9].

Гістологічна верифікація лейоміосаркоми проводиться на основі трьох морфологіних ознак: висока мітотична активність, некроз пухлинних клітин і клітинна атипія. Допоміжними ознаками, які слід враховувати при встановленні діагнозу, $\epsilon$ наявність згаданих вище клінічних симптомів, клімактеричний вік, великі розміри матки, мікроскопічно - осередки некрозу, фігури мітозів [1].

Враховуючи рідкість захворювання та труднощі гістологічної ідентифікації наводимо клінічний випадок лейоміосаркоми матки.
Обговорення. Хвора Ц., 51 рік, шпиталізована в гінекологічне відділення ЦРКЛ 27.04.2016 р. (медична карта стаціонарного хворого № 3008) із скаргами на рясні кров'янисті виділення із статевих шляхів, болі внизу живота, загальну слабкість, запаморочення. Вважає себе хворою протягом одного дня, коли вперше відмітила кровотечу із статевих шляхів.

3 анамнезу. Проживає в задовільних матеріально-побутових умовах. Інфекційні та венеричні хвороби заперечує. Вагітностей дві, пологів двоє, другі шляхом кесаревого розтину (1992р.).

Загальний стан при поступленні задовільний. Шкірні покриви та видимі слизові блідо-рожевого кольору. Печінка, селезінка, нирки, периферійні лімфатичні вузли не збільшені. Розміри серця в межах фізіологічної норми. В легенях прослуховується везикулярне дихання. Пальпаторно живіт м'який, болючий в нижніх відділах. У ділянці пупка справа визначається пухлиноподібний болючий утвір розміром 6×5×5 см (післяопераційна грижа). Набряки відсутні. Температура тіла $36,7^{\circ} \mathrm{C}$.

Гінекологічний статус. Зовнішні статеві органи розвинуті правильно. Піхва виповнена згустками крові. Шийка матки вкорочена до 0,5 cм. Тіло матки збільшене, за розмірами відповідає 18 тижню вагітності, рухоме, болюче, тістуватої консистенції.

Діагноз при поступленні: симптомна фіброміома матки. Маткова кровотеча. Вентральна післяопераційна грижа. Постгеморагічна анемія тяжкого ступеня.

При загальному клініко-лабораторному о6стеженні, окрім показників анемії, відхилень від вікової фізіологічної норми не виявлено. Проведено діагностичне вишкрібання стінок порожнини матки, при подальшому гістологічному дослідженні біопсійного матеріалу виявлено залозис- 
Огляди літератури, оригінальні дослідження, погляд на проблему

ту гіперплазію ендометрія. Хворій проводили гемостатичну терапію, однак на 10 годину після діагностичного вишкрібання розвинулася профузна маткова кровотеча. За життєвими показаннями ургентно проведена нижньосерединна лапаротомія та екстирпація матки з додатками. Післяопераційний період перебігав без ускладнень, 5.05.2016 р. пацієнтка в задовільному стані виписана із стаціонару.

При гістологічному дослідженні операційного матеріалу виявлено суттєві прояви ремоделювання гладких м'язів міометрія. Перед патогістологом постало питання диференціації пухлинного проце- су між лейоміомою та лейоміосаркомою. При типовій міомі затруднень в діагностичному процесі не виникає. Але, як вказує Д. І. Глазунов [1], при наявності дистрофічних процесів як результату невідповідності між кровопостачанням і проліферацією міоцитів, ядра набувають ознак виродливості, великих розмірів, стають гіперхромними. У таких випадках доцільно шукати ознаки злоякісного росту. При саркомі поліморфізм ядер дифузний, а не осередковий, наявні патологічні мітози, некрози, крововиливи [2]. Саме зазначені ознаки злоякісного ремоделювання пухлинного вузла відмічено у нашому спостереженні (рис. 1).

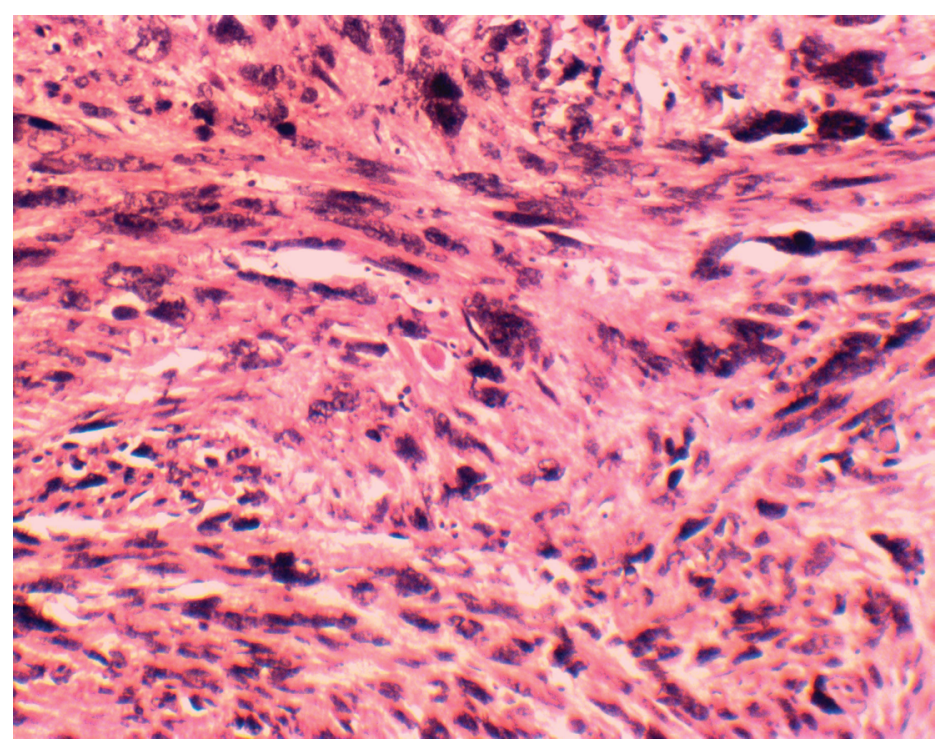

Рис. 1. Лейоміосаркома матки. Гістологічний зріз пухлини. Забарвлення гематоксиліном і еозином. 36.: ок. 10, об. 20.

Висновок. Наведені дані загострюють увагу патоморфологів на труднощах гістологічної верифікації лейоміосаркоми і міоми матки.

\section{ЛІТЕРАТУРА}

1. Головин Д. И. Ошибки и трудности гистологической диагностики опухолей : руководство для врачей. Л. : Медицина, 1982. - 304 с.

2. Сапаргалиева А. Д. Случай лейомиосаркомы в лейомиоме в практике патологоанатома с кратким обзором современной литературы / А. Д. Сапаргалиева // Medicine (Almaty). - 2016. - № 35 (167). - C. 19-24.

3. Франк Г. А. Проблемы морфологической классификации и диагностики опухолей мягких тканей / Г. А. Франк // Практическая онкология. - 2004. - Т. 5, № 4. - C. 231-236.

4. Bodurka D. C. Sarcomas of the female reproductive tract. In: Pollock RE, ed. / D. C. Bodurka, D. M. Gershenson / American Cancer Society Atlas of Clinical Oncology. Soft Tissue Sarcomas. - Hamilton, Ontario : BC Decker, 2002. P. 213-227.

5. The treatment of uterine leiomyosarcoma. Result from a 10-year experience (1990-1999) at the Massachusetts General Hospital / T. A Dinh., E. A. Oliva, A. F. Fuller,
Перспективи подальших досліджень. Для подальшого лікування, контролю і спостереження хвора скерована в обласний онкологічний диспансер.

A. Goodman // Gynecology Oncology - 2004. - Vol. 92, № 2. - P. 648-652.

6. Retrospective review of 208 patients with leiomyosarcoma of the uterus: prognostic indicators, surgical management, and adjuvant therapy / R. L. Giuntoli, D. S. Metzinger, C. S. DiMarco [et al.] // Gynecology Oncology. 2003. - Vol. 89, No. 3. - P. 460-469.

7. Uterine sarcoma: clinic-pathological characteristics, treatment and outcome in Iran / F. Ghaemmaghami, M. K. Zarchi, M. M Gilani [et al.] // Asian Pacific J. Cancer Prev. - 2008. - No. 9. - P. 421-426.

8. Harry V. N. Uterine leiomyosarcomas: a review of the diagnostic and therapeutic pitfalls / V. N. Harry, G. V. Narayansingh, D. E. Parkin // Obstet. and. Gynecology. - 2007. No. 9. - P. 88-94.

9. Uterine leiomyosarcoma that became positive for HMB 45 in the metastasis / E. C. Silva, D. C. Bodurka, M. A. Scouros, A. A. Ayala // Ann. Diagn. Pathology. - 2005.No. 1. - P. 43-45. 
Огляди літератури, оригінальні дослідження, погляд на проблему REFFERENCES

1. Golovin, D.I. (1982). Oshybki i trudnosti gistologicheskoy diagnostiky opukholey: (rukovodstvo dlya vrachey) [Errors and difficulties of gistological diagnostics of tumors]. Lviv: Medytsyna [in Russian].

2. Sapargaliyeva, A.D. (2016). Sluchay leyomyosarkomy $v$ leyomiome $v$ praktike patologoanatoma s kratkim obzorom sovremennoy literatury [The case of leiomyosarcoma in a leiomyoma in the practice of a pathologist with a brief review of modern literature]. Medicine (Almaty), 35 (167), 19-24 [in Russian].

3. Frank, H.A. (2004). Problemy morfologicheskoy klassifikatsyy i diagnostiki opukholey myahkikh tkaney [Problems of morphological classification and diagnosis of soft tissue tumors]. Prakticheskaya onkologiya - Practical Oncology, 5 (4), 231-236 [in Russian].

4. Bodurka, D.C. \& Gershenson, D.M. (2002). Sarcomas of the female reproductive tract. In: Pollock RE, ed. American Cancer Society Atlas of Clinical Oncology. Soft Tissue Sarcomas. - Hamilton, Ontario: BC Decker.
5. Dinh, T.A., Oliva, E.A., Fuller, A.F. \& Goodman, A. (2004). The treatment of uterine leiomyosarcoma. Result from a 10-year experience (1990 - 1999) at the Massachusetts General Hospital. Gynecology Oncology, 92 (2), 648-652.

6. Giuntoli, R.L., Metzinger, D.S., DiMarco, C.S., Cha, S.S., Sloan Keeney, J.A. \& Goustaut, B.S. (2003). Retrospective review of 208 patients with leiomyosarcoma of the uterus: prognostic indicators, surgical management, and adjuvant therapy. Gynecology Oncology, 89 (3), 460-469.

7. Ghaemmaghami, F., Zarchi, M.K., Gilani, M.M., Mousavi, A., Behtash, N. \& Chasemi, M. (2008). Uterine sarcoma: clinic-pathological characteristics, treatment and outcome in Iran. Asian Pacific J. Cancer Prev., (9), 421-426.

8. Harry, V.N., Narayansingh, G.V. \& Parkin, D.E. (2007). Uterine leiomyosarcomas: a review of the diagnostic and therapeutic pitfalls. Obstet. and. Gynecology, (9), 88-94.

9. Silva, E.C., Bodurka, D.C., Scouros, \& Ayala, A.A. Uterine leiomyosarcoma that became positive for HMB 45 in the metastasis. Ann. Diagn. Pathology, (1), 43-45.

\title{
ЛЕЙОМИОСАРКОМА МАТКИ (СЛУЧАЙ ИЗ ПРАКТИКИ)
}

\author{
ОЯ. Я. Боднар, Ю. Н. Орёл, П. С. Крыжан, Л. П. Боднар
}

Гвуз «Тернопольский государственный медицинский университет имени И. Я. Горбачевского Мз Украины»

РЕЗЮМЕ. Среди злокачественных новообразований матки лейомиосаркома встречается в 1-1,3 \% случаев. Чаще всего эту опухоль обнаруживают при изучении операционного материала, поэтому именно гистологическое исследование является основным методом диагностики лейомиосаркомы матки. При этом часто возникают трудности в дифференциации этой опухоли и ее доброкачественного аналога - миомы. В публикации описан случай лейомиосаркомы матки у женщины в возрасте 51 г. Подробно отображены анамнестические и клинические данные, описана динамика развития заболевания. Основное внимание сосредоточено на особенностях микроскопической диагностики лейомиосаркомы матки. Так, при гистологическом исследовании операционного материала выявлены существенные признаки ремоделирования гладких мышц миометрия. Ядра миоцитов имели уродливый вид, увеличивались в размерах, становились гиперхромными, что является индикатором дистрофических процессов в результате несоответствия между кровоснабжением и пролиферацией клеток в злокачественной опухоли. Полиморфизмядернаблюдалсядиффузно, анеочагово. Крометого, визуализировались патологические митозы, некрозы, кровоизлияния. Описанный случай из практики акцентирует внимание патоморфологов на трудностях гистологической верификации лейомиосаркомы и миомы матки.

КЛЮЧЕВЫЕ СЛОВА: лейомиосаркома; матка; гистологическая диагностика.

\section{LEIOMYOSARCOMA OF THE UTERUS (CASE FROM PRACTICE) @Ya. Ya. Bodnar, Yu. M. Orel, P. S. Krizhan, L. P. Bodnar I. Horbachevsky Ternopil State Medical University}

SUMMARY. Among the malignant tumors of the uterus, leiomiosarcoma occurs in $1-1.3 \%$ of cases. This tumor is often detected in the study of the surgical material, so the same histological examination is the main method of diagnosis of leiomyosarcoma of the uterus. In this case, there are often difficulties in differentiating this tumor and its benign analogue leiomyomas. The publication describes the case of leiomyosarcoma of the uterus in a woman of 51 years old. The anamnestic and clinical data are presented in detail; the dynamics of the disease is described. The main focus is on the criteria of microscopic diagnosis of leiomyosarcoma of the uterus. Thus, during histological examination of the surgical material, significant manifestations of myometrium smooth muscle remodeling were revealed. The nuclei of myocytes had signs of degeneracy, acquired large sizes, became hyperchromic, an indicator of dystrophic processes as a result of mismatch between blood supply and cell proliferation in a malignant tumor. The polymorphism of nuclei was observed diffuse, not focal. In addition, pathological mitoses, necrosis, hemorrhages were visualized. The described case of practice accentuates the attention of pathomorphologists on the difficulties of histological verification of leiomyosarcoma and uterine fibroids.

KEY WORDS: leiomyosarcoma; uterus; histological diagnostics. 